\title{
Decompression sickness among Moroami diving fishermen in Jakarta
}

\author{
Chichi Wahab, ${ }^{1}$ Setyawati Budiningsih, ${ }^{2}$ Muhammad Guritno ${ }^{3}$
}

\begin{abstract}
Abstrak
Indonesia merupakan kepulauan dengan jutaan nelayan, namun belum banyak penelitian mengenai penyakit dekompresi (PD). Tujuan penelitian ialah mengidentifikasi prevalensi dan beberapa faktor dominan yang berkaitan dengan kenaikan risiko PD setelah penyelaman. Penelitian dilakukan antara Oktober - November 2007 pada seluruh nelayan peselam Moroami di Kepulauan Seribu Jakarta. Anamnesis dan pemeriksaan dilakuan sebelum dan tiga kali setelah menyelam. Subjek menderita PD jika mengalami salah satu gejala: nyeri sendi, nyeri otot, atau gatal-gatal, lemah tungkai, gangguan buang air besar (obstipasi, melena, diare) atau kecil, pendengaran, penglihayan, sakit kepala, vertigo, sesak napas, nyeri dada, kejang, pingsan, mual, muntah (biasa atau darah). Dari 123 subjek yang potensial, 5 subjek sedang menderita penyakit pernafasan atas, sehingga sebanyak 117 berpartispasi dalam penelitian ini. Sebanyak 62 orang (53\%) menderita PD. Model akhir menunjukkan bahwa mouthpice, valsava bila telinga sakit, peselam perlu kursus menyelam untuk menghindari kecelakaan, dan kecepatan naik merupakan faktor-faktor dominan yang berkaitan dengan PD. Kecepatan naik merupakan faktor risiko yang tertinggi. Peselam yang naik 18 meter per menit atau lebih dibandingkan dengan yang naik kurang dari $18 \mathrm{~m}$ per menit mempunyai risiko dua kali lipat menderita PD [risiko relatif suaian $(R R a)=2.2 ; 95 \%$ interval kepercayaan $(C I)=1,11-3,56]$. Di samping itu peselam yang menderita dibandingkan dengan yang tidak PD sebelum menyelam mempunyai risiko 20\% lebih banyak (95\% CI =0,86-1,68; $p=0,285)$. Di samping penggunaan mouthpice yang baik, cara valsava yang benar, para nelayan tradisional terutama perlu diberikan latihan supaya naik ke permukaan laut kurang dari 18 m per menit untuk mengururangi risiko PD. (Med J Indones 2008; 17: 197-202)
\end{abstract}

\begin{abstract}
Indonesia is an archipelago with many traditional divers, however research on decompression sickness (DCS) has not yet elaborated. The aim of the study was to identify the prevalence of DCS and factors related to it. The study was conducted on October-November 2007 among fisherman moroami divers in Seribu Island Jakarta. Anamnesis and physical examination was taken before and three times after diving. Subject was diagnosed as having DCS if experienced one of these symptom or sign: myalgia, muscle pain, skin rash, ankle weakness, bowel movement \& bladder dysfunction, visual disturbances, headache, vertigo, dyspnoe, chest pain, convulsion, unconsciousness, nausea and vomiting. Among 123 potential divers, five were having upper respiratory infection, so only 117 divers participated in this study. Final model analysis showed that regulator, valsava when having ear pain, ascending speed to surface, and lack of training were risk factors to obtain DCS. Divers whose ascending speed more than $9 \mathrm{~m}$ per minutes had two times risk to get DCS [adjusted ratio $=2.2 ;$ 95\% confidence interval $(C I)=1.11-3.56]$. Having DCS before diving, increased risk 20\% (RRa $=1.20 ; 95 \%$ CI $=0.86-1.68 ; P=0,285)$. Beside knowledge to use regulator correctly and valsava, fisherman Moroami divers need to be trained to ascend speed to sea level surface less than 9 m per minute. (Med J Indones 2008; 17: 197-202)
\end{abstract}

Keywords: decompression sickness, ascending speed, regulator, valsava

Indonesia is the biggest archipelago in the world, consist of 17.508 islands which two third was covered by sea. ${ }^{1}$ Seribu Island is a part of Jakarta province, lies in Jakarta Bay and Jawa Sea. Consisted of 110 islands

\footnotetext{
1 Mintohardjo Navy Hospital, Jakarta, Indonesia

2 Department of Community Medicine, Faculty of Medicine University of Indonesia, Jakarta, Indonesia

3 Indonesian Navy Health Office, Jakarta, Indonesia
}

and has 19.593 population mostly lived in only eleven islands. ${ }^{2}$ Eighty percent are fishermen, which composed of common fisherman and diver-fisherman. There are two clusters in the latest group, the Moroami divers and divers who used spear. ${ }^{3}$

Moroami divers are natural fisherman who used net for catching fishes. ${ }^{1}$ Natural divers meant that they never received formal training, the diving skill was descended from their father or grandfather. They also still used conventional compressor for oxygen supply. 
Diseased pattern and morbidity rate based on health center 2005-2006 data, was still dominated by respiratory tract infection, skin disease and diarrhea, yet no decompression sickness (DCS) was reported. There were eighteen DCS type II cases referred to Mintohardjo Navy Hospital in Jakarta. According to yearly report from Hyperbaric Center Navy Hospital Mintohardjo, 309 cases were referred from Seribu island. Two hundred four $(66 \%)$ cases were fisherman moroami divers where as 175 diagnosed as DCS type II and 29 DCS type I.

Decompression sickness is an occupational hazard, common among fisherman divers and was caused or related with several factors. Low knowledge of diving risk and diving procedure, using simple diving equipment and motivation to catch more fishes were factors increasing the risk of DCS. ${ }^{4}$

EventhoughIndonesiahasmanyfishermancommunities, however, research on hyperbaric among fishermen has not been elaborated. A survey by Hyperbaric Study Program Medical Faculty of Universitas Indonesia in one village in Seribu island discovered that 64 natural divers $(58 \%)$ used conventional compression, 46 $(41,8 \%)$ held their breath. ${ }^{5}$ Another survey reported that $51.8 \%$ from 58 divers experienced decompression. ${ }^{4}$

\section{METHODS}

A cross sectional study was conducted in Seribu island Jakarta during period of August till September 2007. The research population was all moroami fisherman divers who dived around Seribu island and work since morning until evening. Inclusion criteria were 1) lived in Seribu island; 2) dive around Seribu island from morning until evening; 3) using conventional compression; 4) agree to involve in this study.

Data was collected by the first author. Subjects were informed written and orally and signed informed consent if agreed. Data were collected through 1) interview by using questionnaire, 2) physical examination before and after diving, bubble gas examination using Doppler Bubble Detector before \& after diving; 4) compressor level of CO2 by using Kitagawa Gas Detector; 5) Dive Com for diving profile.

Risk factors collected were age, education, duration of work, compressor's CO2 level, diving profile (depth, length of time, frequency and interval between diving), alcohol consumption, diving equipment, knowledge attitude - practice of diving.

Moroami divers are traditional divers and fishermen by profession. They received no formal training to be divers and used conventional equipment, comprised of a mask and pipe for air supply to inhale the air though a regulator

Decompression sickness were diagnosed if one symptom or sign was found: joint pain; muscle pain; malaise; sleepy; skin rash; neurological dysfunction; visual disturbances; bowel movement dysfunction, headache; vertigo; dyspnoe; chest pain; nausea; vomit; or convulsion.

For analysis, data were categorized as follows: age ( $\leq 30 />30$ years); education ( $\leq$ junior high school / senior high school); length of work using conventional compressor $(<1$ year $/ \leq 1$ year), onset of symptom $(<6$ hours $/>6$ hours); body mass index - BMI (underweight $\geq 18.5 /$ normal $=18.5-24.9 /$ obese $\geq 25$ ).

Level of $\mathrm{CO} 2$ was measured from regulator and categorized into $<0.04 \%$ and $\geq 0.04 \%$. Diving profile were categorized as follows: depth $(<18 \mathrm{~m} / \leq 18 \mathrm{~m})$; length of diving $(<50$ minutes $/ \geq 50$ minutes); speed of ascending to sea level $(18 \mathrm{~m}$ per minute $/ \geq 18 \mathrm{~m}$ per minute); frequency of diving ( $<3$ per day $/ \geq 3$ per day). The overall diving profile was categorizes as good $=\geq 3$ and $\mathrm{bad}=<3$. Knowledge and attitude were categorized as good $(>3)$ and bad $(\leq 3)$ while good behavior valued $\geq 3$ and bad is valued is $<3$.

Data were analyzed using Cox regression with Stata program released 9. Ethical clearance was obtained from Ethical Committee of Medical Faculty, University of Indonesia.

\section{RESULTS}

Among 123 potential divers, five were having upper respiratory infection, so only 117 divers participated in this study. Table 1 shows the prevalence of post diving DCS was $53 \%$. Most of the subjects were low educated. Subject who had DCS and without DCS were similar in terms of family burden, and body mass index (BMI). It is less likely that those who are unmarried or widower and has income one to one and halve million rupiah did have DCS than the respective reference risk factor. However, those who age 31-52 age were more likely to be DCS. 
Table 1. Several demographic characteristics, body mass index and risk for decompression sickness (DCS)

\begin{tabular}{|c|c|c|c|c|c|c|}
\hline & & Decol & ession & & & \\
\hline & & & & Crude & $95 \%$ CI & $\mathrm{P}$ \\
\hline & & $\begin{array}{c}\text { No } \\
(\mathrm{n}=55)\end{array}$ & $\begin{array}{c}\text { Yes } \\
(n=62)\end{array}$ & relative risk & & \\
\hline Age group & $18-30$ year & 36 & 31 & 1.00 & Reference & \\
\hline & $31-52$ year & 19 & 31 & 1.34 & $0.81-2.20$ & 0.249 \\
\hline Education & $\begin{array}{l}\text { Primary or junior high } \\
\text { school }\end{array}$ & 53 & 62 & 1.00 & Reference & \\
\hline & Senior high school & 2 & 0 & $\mathrm{~N} / \mathrm{a}$ & & \\
\hline Marital status & Married & 33 & 50 & 1.00 & Reference & \\
\hline & Unmarried/widower & 22 & 12 & 0.59 & $0.31-1.10$ & 0.096 \\
\hline Income (Rp) & 0.7-0.9 million rupiah & 20 & 43 & 1.00 & Reference & \\
\hline & 1.0-1.5 million rupiah & 35 & 19 & 0.52 & $0.30-0.88$ & 0.016 \\
\hline Family & 0-3 persons & 51 & 54 & 1.00 & Reference & \\
\hline & 4-5 persons & 4 & 8 & 1.30 & $0.62-2.72$ & 0.493 \\
\hline Body Mass Index & Normal & 45 & 56 & 1.00 & Reference & \\
\hline & Skinny & 3 & 3 & 0.90 & $0.28-2.88$ & 0.862 \\
\hline & Obese & 7 & 3 & 0.54 & $0.17-1.73$ & 0.300 \\
\hline
\end{tabular}

$\mathrm{N} / \mathrm{a}=$ Not applicable

Table 2 shows that subjects who did and did not have DCS were similarly distributed in terms of knowledge about the need for physical examination before diving, examination by a hyperbaric's specialist, prevention of accident, divers may dive alone and not panic in danger situation. Furthermore, it seems that less likely to have
DCS were those who knew the cause of accident, diving trainer must know the danger of diving, may use dysfunction diving equipment. However, those who agreed that divers need to attend diving course were more likely to be DCS.

Table 2. Some knowledge concerning physical examination, accident, trainer and attitude of divers to decompression sickness

\begin{tabular}{|c|c|c|c|c|c|c|}
\hline & & \multicolumn{2}{|c|}{$\begin{array}{c}\text { Decompression } \\
\text { sickness } \\
\end{array}$} & \multirow{2}{*}{$\begin{array}{l}\text { Crude } \\
\text { relative risk }\end{array}$} & \multirow{2}{*}{$95 \% \mathrm{CI}$} & \multirow{2}{*}{$\mathrm{P}$} \\
\hline & & $\begin{array}{c}\text { No } \\
(n=55)\end{array}$ & $\begin{array}{c}\text { Yes } \\
(n=62)\end{array}$ & & & \\
\hline \multirow[t]{2}{*}{ Physical examination needed before diving } & Yes & 47 & 52 & 1.00 & Reference & \\
\hline & No & 8 & 10 & 1.06 & $0.54-2.08$ & 0.871 \\
\hline \multirow{2}{*}{$\begin{array}{l}\text { Physical examination has to be done by a } \\
\text { submarine specialist }\end{array}$} & Yes & 26 & 30 & 1.00 & Reference & \\
\hline & No & 29 & 32 & 0.98 & $0.60-1.61$ & 0.934 \\
\hline \multirow[t]{2}{*}{ Accident can be prevented } & Yes & 31 & 38 & 1.00 & Reference & \\
\hline & No & 24 & 24 & 0.91 & $0.54-1.51$ & 0.711 \\
\hline \multirow[t]{2}{*}{ Divers needed to be trained } & Yes & 49 & 32 & 1.00 & Reference & \\
\hline & No & 6 & 30 & 2.11 & $1.28-3.47$ & 0.003 \\
\hline \multirow[t]{2}{*}{ Divers may diving alone } & Yes & 48 & 53 & 1.00 & Reference & \\
\hline & No & 7 & 9 & 1.07 & $0.56-2.17$ & 0.847 \\
\hline \multirow[t]{2}{*}{ May use dysfunction diving equipment } & Yes & 12 & 31 & 1.00 & Reference & \\
\hline & No & 43 & 31 & 0.58 & $0.35-0.96$ & 0.033 \\
\hline \multirow[t]{2}{*}{ Not panic in danger situation } & Yes & 46 & 50 & 1.00 & Reference & \\
\hline & No & 9 & 12 & 1.09 & $0.58-2.06$ & 0.773 \\
\hline \multirow[t]{2}{*}{ Performing valsava when ear pain } & Yes & 10 & 24 & 1.00 & Reference & 0.097 \\
\hline & No & 45 & 38 & 0.65 & $0.89-1.08$ & \\
\hline
\end{tabular}


Table 3 shows that subjects who did and who did not have DCS were similarly distributed in terms of physical examination and consultation every 6 months and may drink alcohol before/after diving. Those who knew that it was forbidden to dive when one's has headache / stress were more likely to have DCS. While diver, who knew that he need to rest 10 minutes if diving more than 1 per day and may dive 3 times per day in diving less than 30 meters, were less likely to have DCS.
Our final model (Table 4) shows that regulator, valsava when there is an ear pain, divers need training to avoid accident, ascending speed to sea level were related to DCS. Ascending speed was the greatest risk factor for having DCS. In the first diving, diver who ascended 9 meters or more per minute will have two times risk compare to divers who ascend less than 9 meters.

Table 3. Some behavior of divers concerning physical examination, frequency of diving and attitude toward risk in having decompression sickness

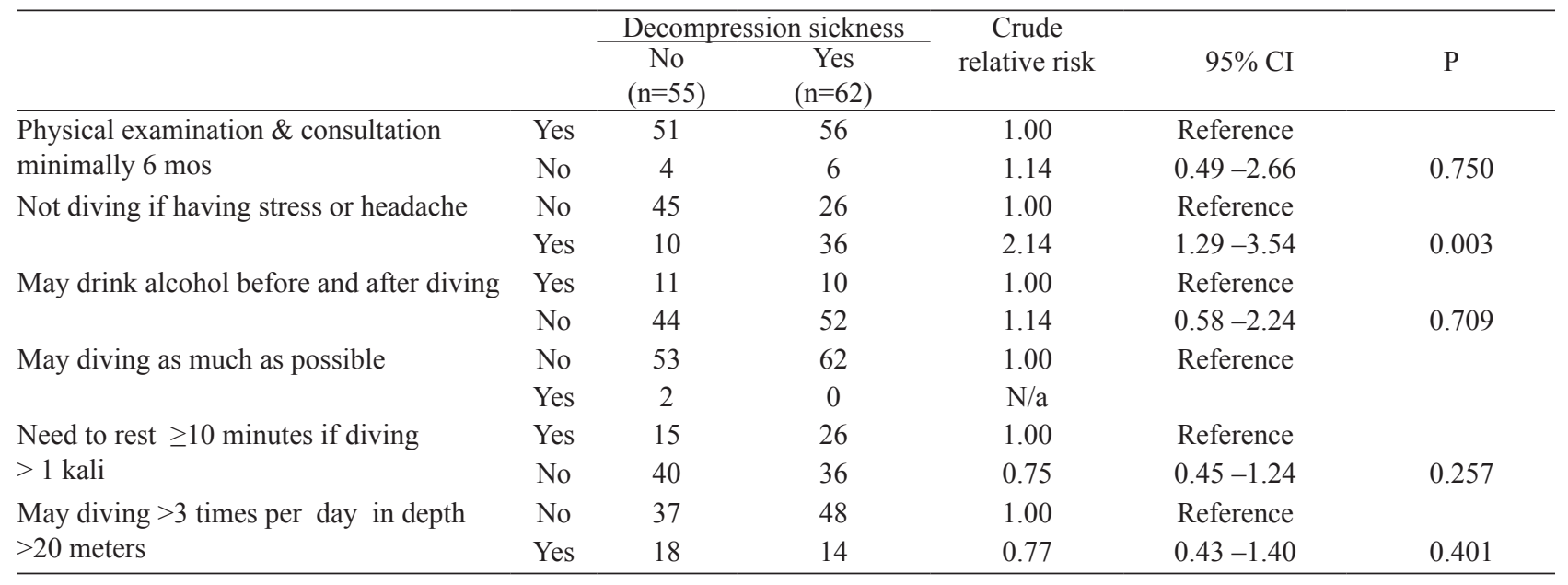

$\mathrm{N} / \mathrm{a}=$ Not applicable

Table 4. Relationship among equipment, knowledge, speed ascending, and risk of having decompression sickness

\begin{tabular}{|c|c|c|c|c|c|c|}
\hline & & \multicolumn{2}{|c|}{ Decompression sickness } & \multirow{2}{*}{$\begin{array}{c}\text { Adjusted } \\
\text { relative risk* }\end{array}$} & \multirow[b]{2}{*}{$95 \% \mathrm{CI}$} & \multirow[b]{2}{*}{$\mathrm{P}$} \\
\hline & & $\begin{array}{c}\text { No } \\
(\mathrm{n}=55)\end{array}$ & $\begin{array}{c}\text { Yes } \\
(n=62)\end{array}$ & & & \\
\hline \multirow[t]{2}{*}{ Type of regulator used } & Good & 51 & 46 & 1.00 & Reference & \\
\hline & No good & 4 & 16 & 1.88 & 1.402 .54 & 0.000 \\
\hline \multirow[t]{2}{*}{ Valsava when have ear pain } & Wrong & 10 & 24 & 1.00 & Reference & \\
\hline & Right & 45 & 38 & 0.70 & $0.52-0.94$ & 0.000 \\
\hline \multirow[t]{2}{*}{ Divers need trained before diving } & Right & 49 & 32 & 1.00 & Reference & \\
\hline & Wrong & 6 & 30 & 1.81 & $1.36-2.42$ & 0.000 \\
\hline \multirow[t]{2}{*}{ Using dysfunction equipment } & May & 12 & 31 & 1.00 & Reference & \\
\hline & May not & 43 & 31 & 0.67 & $0.49-0.92$ & 0.013 \\
\hline \multirow[t]{2}{*}{ First ascending speed } & $\leq 9$ meter & 26 & 6 & 1.00 & Reference & \\
\hline & $\geq 9$ meter & 29 & 56 & 2.02 & $1.11-.56$ & 0.015 \\
\hline \multirow[t]{2}{*}{ Second ascending speed } & $\leq 9$ meter & 28 & 6 & 1.00 & Reference & \\
\hline & $\geq 9$ meter & 27 & 56 & 1.97 & $0.97-3.98$ & 0.059 \\
\hline \multirow[t]{2}{*}{ Third ascending speed } & $\leq 9$ meter & 50 & 26 & 1.00 & Reference & \\
\hline & $\geq 9$ meter & 5 & 36 & 1.69 & $1.27-2.25$ & 0.000 \\
\hline \multirow[t]{2}{*}{ Decompression sickness before diving } & No & 44 & 11 & 1.00 & Reference & \\
\hline & Yes & 35 & 27 & 1.20 & $0.86-1.68$ & 0.285 \\
\hline
\end{tabular}

*Adjusted each other among variable on this Table 


\section{DISCUSSION}

There are limitations in this study. Among others, the population were only fishermen moroami diver who works daily, therefore not represent the fishermen as well as Seribu island population. Secondly, potential bias which could occurred in the interview as questionaire was used in this study, even though a guideline has been used.

Prevalence of DCS in this study was $53 \%$. The prevalence was lower compared to prevalence found at Mintohardjo Navy Hospital in Jakarta (62\%).This may be due to the difference source of population. Cases at Mintohardjo hospital came from all fishermen diver population in Seribu island, while this study covered Moroami divers only. A previous similar study (1996) in Panggang island (the biggest) in Seribu island shows a slight difference in DCS prevalence after diving $(52 \%) .^{5}$

There was an increased percentage of DCS after compare to before diving. Divers who had DCS before diving, have a $20 \%$ increase for having DCS than divers who had no history of DCS.

In this study, divers with age 30 years or more had a higher risk to be DCS than divers age less than 30 years. Other study ${ }^{5}$ shows different result, 93\% among divers aged 30 year or more had DCS, while $6.9 \%$ among aged less than 30 year. Another study ${ }^{6}$ found that $38 \%$ DCS among divers age $>30$ years and $62 \%$ among age $<30$ year. Differences among these study could be due to degeneration process at age $>30$ year. With length of work $>10$ years as a diver, result in having DCS before this study due to the formation of core bubble. Therefore, if he dived not according standard operational procedure, a higher risk of DCS will occur because bubble core was already formed. ${ }^{7}$

Furthermore, in our study noted that obese reduced the risk of having DCS even though not significant. The previous study ${ }^{5}$ did not provide similar information because the BMI was not well distributed. While the other study ${ }^{6}$ showed that $59.3 \%$ divers with abnormal BMI had DCS. This difference was based on theory that N2 has 4-5 times higher dilution rate in fat tissue than in other tissue. ${ }^{7-9}$

Statistical analysis found a significant increasing risk to and have DCS after diving and with having diving 3 times or more. Three times diving were safe procedures, however fishermen moroami dived more than 3 times due to the need to have enough income. Overall, this study shows similar result concerning knowledge of procedural for diving. ${ }^{4}$

A significant relationship was also found between compressor condition before diving. A cared compressor reduced DCS risk, many factors caused this situation. In this study, eventhough the compressor was not well cared however some factors as using a standard oil for diving, length between outlet - inlet more than $1 \mathrm{~m}$ and level of $\mathrm{CO} 2<0.04 \%$ due to the wind flow, explained this situation.

Before diving, knowledge on diving procedure concerning (not perform valsava when have ear pain) had a significant increased risk for DCS. This means that knowlwdge for performing valsava is an important information needed by the divers. Moroami divers who did not perform valsava had 30\% higher risk to be DCS compare to other knowledge. Not performing valsava when had an ear pain will caused barotrauma. This condition will caused vertigo if the ascending speed is $>9 \mathrm{~m}$ per minute. ${ }^{7,10,11}$

In this study it was also proved that the first, second and third ascending speed in diving less than $9 \mathrm{~m}$ per minute increased the risk of having DCS. This is similar with the previous study. ${ }^{6}$

Conclusion. More than $50 \%$ on fishermen Moroami diver had DCS after diving. Dominant factors related to DCS were using regulator, performing valsava, uncared compressor, ascending speed to sea level more than 9 $\mathrm{m}$ per minit, and previous DCS. Training on diving procedure is needed especially concerning ascending speed to sea level.

\section{REFERENCES}

1. D. Pramono. Nusantara maritime, maritime culture [Indonesian]. Jakarta. Gramedia. 2005.

2. B. Bahar. Fishery products in Indonesian [Indonesian]. Bogor. Buana Printing. 2004.

3. Clarke D. Decompression sickness, theory and treatment. Deep diving. Best Publishing Co. 1995.

4. Department of Community Medicine of Univ Indonesia. Survey on fisherman divers in Panggang Island [Indonesian]. Jakarta. The Department. 1994.

5. Susan Simanungkalit. Analysis on decompression sickness among divers who used traditional compressors in Panggang Island, Jakarta [Indonesian] [thesis]. Jakarta. Univ Indonesia. 1997. 
6. I Bagus Nyoman Banjar. Several risk factors related to decompression sickness among traditional divers in Panggang Island Jakarta [thesis]. Jakarta. Univ Indonesia. 2005.

7. Jain KK. Decompression Sickness. Textbook of Hyperbaric Medicine. Toronto. Hogrefe \& Huber Publisher. 1999.

8. Elliot DH. Decompression sickness. Hyperbaric Medicine Practice. Best Publishing; 1994.
9. Edmonds C, Lowry C, Pennefather J. Decompression sickness. Diving and sub aquatic Medicine. Oxford. Oxford Univ Press. 2002.

10. Dutka AJ, Francis TJ. Pathophysiology of decompression sickness. Diving Medicine. London. Saunders. 1997.

11. Gorman DF, Francis TJR. Pathogenesis of the Decompression Disorders. London. Saunders. 1993. 